\title{
Bond Strength of Bamboo Reinforcement in Light Weight Concrete
}

\author{
Nindyawati and Baiq Sri Umniati \\ Jurusan Teknik Sipil Fakultas Teknik, Universitas Negeri Malang, Malang 65144, Indonesia
}

\begin{abstract}
Bamboo reinforced concrete as a building material is expected to be an alternative to steel reinforced concrete. Due to the fact that steel is not renewable and polluting steel mills are fairly high. The bond strength is a major concern for the natural fiber used as reinforcement in structural composites. This paper reports study on the bond strength of bamboo reinforcement in concrete, to determine the adhesion reinforcement in concrete often do by the pull-out test. The research objective was bond strength of lightweight concrete and bamboo reinforcement. The test used light weight concrete with foam additives klerak. Bamboo slats were coated with paint and sprinkled with sand. The results obtained showed that the bond strength bamboo $60 \%$ of the bond strength steel.
\end{abstract}

Key word: Bamboo, reinforcement, pull-out test, light weight concrete, strong adhesion bamboo $60 \%$ of the strong adhesion of steel.

\section{Introduction}

Bamboo has many unique properties that make it strong and suitable to be used as a construction material. Concrete is used for most building. The most reinforcement material for concrete is steel. Steel needs great energy to produce and can not be renewed. Even some countries do not have the steel. Bamboo however, is more cheap and renewable.

The usual assumptions in the design and analysis of concrete structures are the bond strength reinforcement with concrete surrounding. It is completed without sliding. Based on that assumption, the bamboo reinforced concrete supports surface tension bond between the bamboo and concrete. For beam structures that resist bending moment, bond strength is equivalent to the variation of changes in the value of the bending moment along the beam. Changing the value of longitudinal bending moment results interaction between bamboo reinforcement and concrete, so that the tensile stress along the bamboo reinforcement should be arrested.

The simple pull-out test is widely used to evaluate

Corresponding author: Nindyawati, Dr., research field: structure. bonding with concrete reinforcement. In the pull-out test, concrete reinforcement is pulled so that the concrete around it is reinforced. Bond behavior actually occurs in concrete beams reinforcement not like the pull-out test. Reinforcement and surrounding concrete experience both tensile [1]. Strong adhesion to concrete reinforcement depends on main factor [2] that the bond between concrete and reinforcement. Effect is gripping (holding) as a result of the drying shrinkage of concrete around the reinforcement. Bamboo swells up as it absorbs water. This swelling up might cause voids and loss of adhesion between the surface of bamboo and the concrete. When bamboo shrinks and dries, it could lead to failure in the concrete structure. To counter this problem is to coat the bamboo with a water resisting coating.

Resistance friction slipped and locked together when experiencing tensile reinforcement. It also increased the resistance to slip. Effects of quality tensile strength of concrete influence attached to bond strength of bamboo. The bamboo slats were coated with paint and sprinkled with sand. Sand serves to increase the gripping effect on bamboo reinforcement [3]. 


\section{Method}

Bamboo culms, paint, cement, sand, klerak foam and water are used in this investigation.

\subsection{Bamboo}

The brown coloured Apus bamboos are selected, which indicates that the plant is at least three years old. The culms seasoned before use so that starch of bamboo will be lost and insect attacks will be minimised which is used for construction. The bamboo culms are split or cut by means of hand knife, aerated for two days to reduce the moisture content in bamboo.

\subsection{Paint}

Bamboo receives a waterproof coating to minimise swelling. Paint "MAWAR" is used as water proofing in research.

\subsection{Concrete}

The concrete mix proportion (cement:sand) is $2: 3$. Water, foam and cement ratio is 0.60 . Concrete is expected of lightweight. The foam of lerek is sticky, able to keep the bubbles in the concrete mixture.

\subsection{Experimental Program}

Tests conducted were: concrete compressive strength testing, tensile testing of bamboo, pull-out tests and beam bending test.

Preparation of test specimens and testing used the following tools: stirring concrete compression machine with a capacity of $2,000 \mathrm{~kg}$ to test the compressive strength of concrete; UTM (universal testing machine) of two-ton capacity used for tensile testing of bamboo and pull-out test. Tests performed on the flexural strength of concrete loading frame equipped with hydraulic jacks and load cells. The number of specimens for each type of test is shown in Table 1, and the test object is shown in Fig. 1.

\subsubsection{Concrete Compressive Strength Testing}

Lightweight concrete is made from cement, sand,
Table 1 Objects Test.

\begin{tabular}{lll}
\hline No. & Type of testing & Number of specimens \\
\hline 1 & Concrete compressive & 6 \\
2 & strength testing & 6 \\
3 & Tensile testing of bamboo & 6 \\
\hline
\end{tabular}

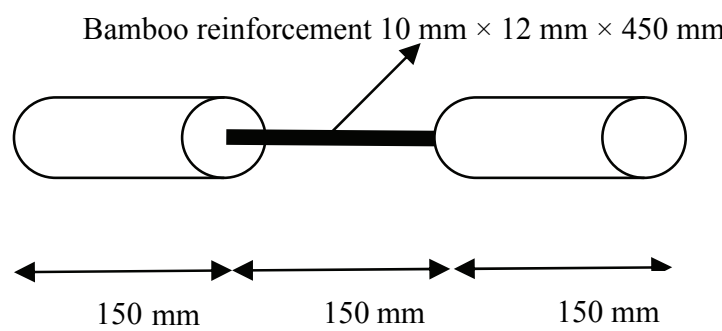

Fig. 1 Samples pull-out test.

water and foam klerak. The sand used was Malang sand. Specimens were cylinders with a diameter of $150 \mathrm{~mm}$ and height of $300 \mathrm{~mm}$. Concrete cylinder covered with plastic for 28 days so as not to get wet. Specimens were weighed before test. The samples were placed in compressive testing machine of capacity $2,000 \mathrm{kN}$. The load is applied parallel to concrete in gradual increments until the sample failure, determined compressive stress at ultimate load.

\subsubsection{Tension Testing of Bamboo}

Apus bamboo samples of length $400 \mathrm{~mm}$ was used. Bamboo specimen with dimension of $8 \mathrm{~mm} \times 8 \mathrm{~mm}$. Tension test procedure for bamboo is as same as that of steel. Load and elongation readings for sample placed in UTM are recorded.

\subsubsection{Pull-Out Tests Specimen}

Apus bamboo of 450-mm length and split of $8 \mathrm{~mm} \times 8 \mathrm{~mm}$ are used. Bamboo coated paint and sprinkled with sand. Concrete cylinders of size $75-\mathrm{mm}$ diameter and 150-mm length are used for test. The bamboos specimens were placed at center in concrete cylinders while casting. The samples were tested after 28 days of curing are tested in machine of capacity $15 \mathrm{kN}$.

Bond length $\left(l_{d}\right)$ is the length of bamboo which is in contact with concrete in cylinder. The bond stress is determined from ultimate load using formula [4]:

$$
\left.u=\frac{P}{\pi \cdot d_{b} \cdot l_{d}} \quad \text { (unit in } \mathrm{N} / \mathrm{mm}^{2}\right)
$$


where, $P$ is the ultimate load at failure, $d$ is the diameter of specimen.

Bamboo reinforcement can be detached from the concrete because split in the longitudinal direction, when the high frictional adhesion or defense happens. When the bamboo reinforcement can be separated out and leave a hole in the concrete, there is low adhesion or friction [5].

\section{Test Results and Discussions}

\subsection{Concrete Compressive Strength Test}

The failure of concrete is observed as compression failure. Curing of light weight concrete is 30 days. The compression test using UTM. The addition of foam and water klerak $60 \%$ of the cement cause low concrete compressive strength (Table 2). Klerak foam forms cavities in the concrete so that the concrete compressive strength is low. Cavity causes bonding among aggregate reduces. When under pressure, concrete was easily spalled as aggregate bonding was brittle.

Average compressive strength of light weight concrete is $12.7 \mathrm{MPa}$. None of the results of compressive strength has a value of less than 0.85 average compressive strength of concrete. The advantages of foam klerak is a light weight concrete. Weight concrete cylinders in the study was $66 \mathrm{~N}$. Volume weight concrete cylinder is $1,240 \mathrm{kN} / \mathrm{m}^{3}$.

\subsection{Tensile Testing of Bamboo}

Bamboo weakness located on the node after the split. The failure of bamboo members is observed mainly as node failure. Selected bamboo with node point at 1/4 length from each end [6]. Bamboo coated paint and sprinkled with sand. The failure of bamboo is split failure at middle of specimen (Fig. 2). The failure pattern was shown in Table 3.

Bamboo tensile test results showed that the average maximum stress that occurs is $139 \mathrm{MPa}$. Apus bamboo has a relatively small tensile strength than the Ori bamboo. The advantages of Apus bamboo is that the straight is so suitable for the walls. Apus bamboo size of average is $8.3 \mathrm{~mm} \times 8.3 \mathrm{~mm}$. The average strain of Apus bamboo is 0.0084 . Modulus elasticity of Apus bamboo is $16,454 \mathrm{MPa}$.

\subsection{Pull-out Tests}

Pull-out test results of the testing can be seen in Table 4. The length of reinforcement embedded in concrete is $300 \mathrm{~mm}$. The average maximum load that can be accepted is $318 \mathrm{~kg}$ or $3.2 \mathrm{kN}$. Bond strength of bamboo to the concrete average is $0.41 \mathrm{MPa}$.

Table 2 Light weight concrete compressive strength test.

\begin{tabular}{lll}
\hline Sample No. & $\begin{array}{l}\text { Concrete compressive } \\
\text { strength }\left(\mathrm{N} / \mathrm{mm}^{2}\right)\end{array}$ & $\begin{array}{l}\text { Weight of cylinder } \\
(\mathrm{N})\end{array}$ \\
\hline 1 & 12.8 & 68 \\
2 & 11.9 & 59 \\
3 & 13.2 & 68 \\
4 & 13.5 & 69 \\
5 & 12.9 & 65 \\
6 & 11.8 & 66 \\
Average & 12.7 & 66 \\
\hline
\end{tabular}

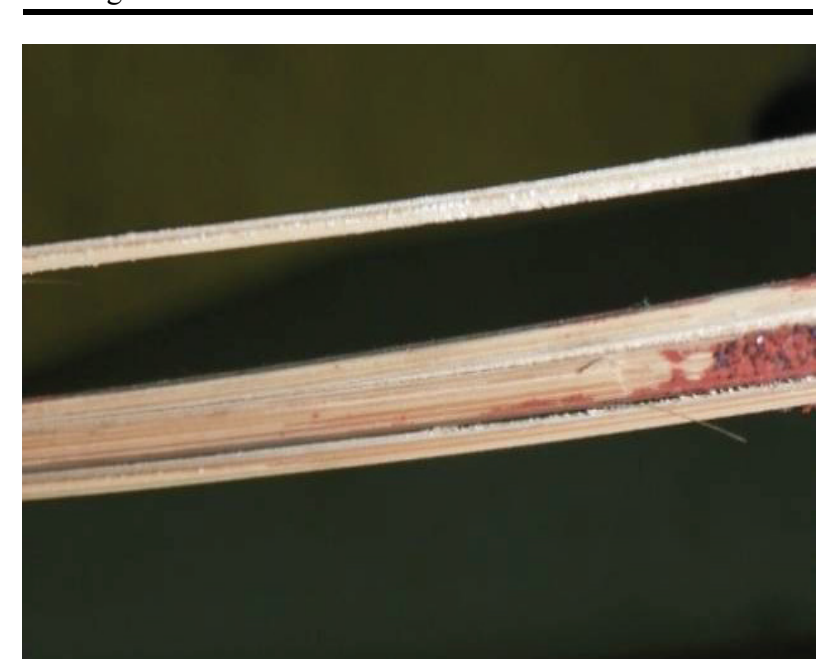

Fig. 2 Splitting failed sample in tensile test.

Table 3 Tensile test for bamboo.

\begin{tabular}{lll}
\hline Sample No. & Strain $(\mathrm{mm} / \mathrm{mm})$ & $\begin{array}{l}\text { Ultimate tensile stress of } \\
\text { bamboo }\left(\mathrm{N} / \mathrm{mm}^{2}\right)\end{array}$ \\
\hline 1 & 0.0082 & 135.9 \\
2 & 0.0080 & 133.5 \\
3 & 0.0090 & 144.0 \\
4 & 0.0083 & 136.4 \\
5 & 0.0084 & 139.8 \\
6 & 0.0089 & 144.2 \\
Average & 0.0084 & 139.0 \\
\hline
\end{tabular}


Table 4 Pull-out Test.

\begin{tabular}{lll}
\hline Sample No. & Load $(\mathrm{N})$ & Bond strength $\left(\mathrm{N} / \mathrm{mm}^{2}\right)$ \\
\hline 1 & 2,500 & 0.33 \\
2 & 4,000 & 0.48 \\
3 & 3,000 & 0.39 \\
4 & 3,500 & 0.45 \\
5 & 2,600 & 0.34 \\
6 & 3,500 & 0.45 \\
\hline
\end{tabular}

Reinforcement did not yield, as well as the concrete had not been spalling. Reinforcement has shifted rapidly over $2.5 \mathrm{~mm}$. Bamboo comes out smoothly from concrete while testing and these values obtained are due to bond failure. Pull-out failure occurred due to the shear strength between the bamboo and the concrete.

The amount bond by direct tension pull-out bond test is $0.41 \mathrm{MPa}$ and bond beam reinforcement at the rate is $1.49 \mathrm{MPa}$. Bond by direct tension pull-out bond test is only $28 \%$ of the bond beam reinforcement. Bond by direct tension pull-out bond test is not accurate for use in the calculation of the bond beam reinforcement.

\section{Conclusions}

Bond strength reinforcement calculations based on direct tension pull-out bond test is less than bond strength reinforcement that occurs on the beam. Bond strength reinforcement by direct tension pull-out bond test should be adapted to take account of the real bond strength reinforcement in beams.

\section{Acknowledgments}

The authors would like to thank Dikti (Hibah Bersaing).

\section{References}

[1] Elagroudy, H. 2003. "Bond Characteristics of Micro-composite Multistructural Formable Steel Used in Reinforced Concrete Structures." M.Sc. thesis, North Carolina State University.

[2] Nawy, E. G. 1998. Concrete as a Basic Approach, Moulds II. Bandung: Penerbit Refika Aditama. (in Indonesian)

[3] Ghavami, K. 2005. "Bamboo as Reinforcement in Structural Concrete Elements". Journal of Cement and Concrete Composites 27 (6): 637-49.

[4] Park, R., and Paulay, T. 1975. Reinforced Concrete Structure. New York: John Wiley and Son Inc.

[5] Nindyawati, S. M. D., and Agoes, S. 2013. "The Comparison between Pull-Out Test and Beam Bending Test to the Bond Strength of Bamboo Reinforcement in Light Weight Concrete." International Journal of Engineering Research and Applications 3 (1): 1497-1500

[6] Sakaray, H. 2012. "Investigation on Properties of Bamboo as Reinforcing Material in Concrete.". International Journal of Engineering Research and Applications 2 (1): 77-83. 